\title{
THE ROLE OF CORRECTIONAL SOCIAL WORKERS IN PERSONALITY DEVELOPMENT IN YOGYAKARTA NARCOTICS CORRECTIONAL
}

\author{
Muhammad Ali Equatora \\ Community Guidance of Correctional \\ Polytechnic of Correctional Science, \\ Depok, Indonesia. \\ Rachmayanthy \\ Technic of Correctional \\ Polytechnic of Correctional Science, \\ Depok, Indonesia.
}

\author{
Galogo Sakti \\ Technic of Correctional \\ Polytechnic of Correctional Science, \\ Depok, Indonesia. \\ Shinta Muliati \\ Correctional Social Worker \\ Palembang, Indonesia
}

\begin{abstract}
Abtract - This Research focuses on the role of correctional social workers in personality development in Yogyakarta Narcotics Correctional Institution as an effort to restore life, life, and livelihood of prisoners. This study aims to describe the role function of correctional social workers in carrying out the development of personality as an effort to restore life, life, and livelihood for the Prisoners of Correctional Institution and to know what constraints faced in the implementation of the coaching program.

This research using Qualitative-Descriptive method on describe the problems discussed on the study. Qualititative-Descriptive research is a research that intended to understand what were felt by the research's subjects, hollisticaly and descriptive in forms of words and language a special context which utilize natural method (Lexy Moloeng, 2007).

Based on the results of research that has been done, it is known that the role of correctional social workers in personality development as an effort to restore life, life, and livelihood of prisoners built not yet functioning properly. The obstacles encountered are the lack of experts in the field of personality development, lack of coaching correctional social workers, and not yet maximize the cooperation with third parties in the implementation of personality guidance program. In this writing, the authors provide suggestions that are proposed additional personality coaching correctional social workers and held education and training about the guidance of personality to the correctional social workers.
\end{abstract}

Keywords_Correctional Social Workers, Personality Development, Prisoners.

\section{INTRODUCTION}

In the development of society, criminal justice system have been changed significantly. In the beginning of criminal justice system was based on revenge on criminals' wrongdoing. As time goes on, the system much more focused on the valid regulations and the criminals were guided in many aspects while serving their time in correctional institution. This guidance is intnded to be criminal offender's capital when they get back to society.

Reports of Narcotics Criminal Act's Criminals/Detainee in Intellectual Activity and Nationalism Awareness in Indonesia's Correctional Institutions

Month: October 2017

\begin{tabular}{|c|c|c|c|c|c|c|c|c|c|}
\hline \multirow{2}{*}{$\begin{array}{l}\mathbf{N} \\
\mathbf{O} \\
.\end{array}$} & \multirow{2}{*}{ Activities } & \multicolumn{8}{|c|}{ NARKOTICS } \\
\hline & & \multicolumn{4}{|c|}{ WNI } & \multicolumn{4}{|c|}{ WNA } \\
\hline \multirow{6}{*}{1} & \multirow{3}{*}{$\begin{array}{c}\text { EDUCAT } \\
\text { ION } \\
\text { BACKG } \\
\text { ROUND }\end{array}$} & \multicolumn{2}{|c|}{ NAPI } & \multicolumn{2}{|c|}{ TAH } & \multicolumn{2}{|c|}{ NAPI } & \multicolumn{2}{|c|}{ TAH } \\
\hline & & M & W & M & W & $\mathrm{M}$ & W & M & W \\
\hline & & & & & & & & & \\
\hline & a. Illiterate & $\begin{array}{c}17 \\
7\end{array}$ & 35 & 31 & 6 & 6 & 3 & 0 & 0 \\
\hline & $\begin{array}{c}\text { b. Not } \\
\text { Finished } \\
\text { (Elementa } \\
\text { ry) }\end{array}$ & $\begin{array}{l}11 \\
97\end{array}$ & $\begin{array}{c}12 \\
0\end{array}$ & $\begin{array}{c}31 \\
3\end{array}$ & $\begin{array}{l}2 \\
2\end{array}$ & $\begin{array}{l}1 \\
2\end{array}$ & 1 & 2 & 0 \\
\hline & $\begin{array}{c}c . \\
\text { Elementar } \\
\text { y School }\end{array}$ & $\begin{array}{l}52 \\
28\end{array}$ & $\begin{array}{c}55 \\
5\end{array}$ & $\begin{array}{l}12 \\
86\end{array}$ & $\begin{array}{l}5 \\
5\end{array}$ & $\begin{array}{l}5 \\
1\end{array}$ & 6 & $\begin{array}{l}1 \\
1\end{array}$ & 0 \\
\hline
\end{tabular}


International Journal of Engineering Applied Sciences and Technology, 2020

Vol. 4, Issue 9, ISSN No. 2455-2143, Pages 1-6

Published Online January 2020 in IJEAST (http://www.ijeast.com)

\begin{tabular}{|c|c|c|c|c|c|c|c|c|c|}
\hline & $\begin{array}{c}\text { d. Junior } \\
\text { High } \\
\text { School } \\
\end{array}$ & $\begin{array}{l}71 \\
94\end{array}$ & $\begin{array}{c}77 \\
9\end{array}$ & $\begin{array}{l}18 \\
13\end{array}$ & $\begin{array}{l}9 \\
7\end{array}$ & $\begin{array}{l}7 \\
3\end{array}$ & $\begin{array}{l}1 \\
7\end{array}$ & $\begin{array}{l}1 \\
1\end{array}$ & 2 \\
\hline & $\begin{array}{l}\text { e. Senior } \\
\text { High } \\
\text { School }\end{array}$ & $\begin{array}{l}93 \\
83\end{array}$ & $\begin{array}{l}12 \\
23\end{array}$ & $\begin{array}{l}31 \\
37\end{array}$ & $\begin{array}{l}1 \\
6 \\
0 \\
\end{array}$ & $\begin{array}{l}1 \\
9 \\
4 \\
\end{array}$ & $\begin{array}{l}5 \\
5\end{array}$ & $\begin{array}{l}2 \\
0\end{array}$ & 3 \\
\hline & $\begin{array}{l}\text { f. Diploma } \\
\text { Degree }\end{array}$ & $\begin{array}{c}40 \\
7 \\
\end{array}$ & 63 & $\begin{array}{c}12 \\
2 \\
\end{array}$ & $\begin{array}{l}3 \\
5 \\
\end{array}$ & $\begin{array}{l}1 \\
9 \\
\end{array}$ & 5 & 2 & 0 \\
\hline & $\begin{array}{c}\text { g. } \\
\text { bachelor's } \\
\text { degree }\end{array}$ & $\begin{array}{c}35 \\
8\end{array}$ & 70 & $\begin{array}{c}13 \\
2\end{array}$ & $\begin{array}{l}1 \\
9\end{array}$ & $\begin{array}{l}2 \\
1\end{array}$ & $\begin{array}{l}1 \\
5\end{array}$ & 4 & 0 \\
\hline \multirow{7}{*}{2} & $\begin{array}{c}\text { FORMA } \\
\text { L } \\
\text { EDUCAT } \\
\text { ION } \\
\end{array}$ & & & & & & & & \\
\hline & a. Paket A & 62 & 23 & 2 & 0 & $\begin{array}{l}1 \\
3 \\
\end{array}$ & 3 & 0 & 0 \\
\hline & b. Paket B & 87 & 40 & 2 & 0 & 9 & 0 & 0 & 0 \\
\hline & c. Paket C & $\begin{array}{c}11 \\
3 \\
\end{array}$ & 60 & 5 & 0 & 9 & 1 & 0 & 0 \\
\hline & $\begin{array}{c}\text { d. } \\
\text { Bachelor } \\
\end{array}$ & 0 & 20 & 0 & 0 & 0 & 0 & 0 & 0 \\
\hline & e. PKBM & 0 & 0 & 0 & 0 & 0 & 0 & 0 & 0 \\
\hline & f. Others & 0 & 0 & 0 & 0 & 0 & 0 & 0 & 0 \\
\hline \multirow{5}{*}{3} & $\begin{array}{c}\text { COURSE } \\
\mathrm{S}\end{array}$ & & & & & & & & \\
\hline & a. Arabian & 8 & 0 & 0 & 0 & 0 & 0 & 0 & 0 \\
\hline & b. English & 8 & 14 & 0 & 0 & 0 & 1 & 0 & 0 \\
\hline & $\begin{array}{c}\text { c. } \\
\text { Computer }\end{array}$ & 14 & 0 & 0 & 0 & 0 & 0 & 0 & 0 \\
\hline & d. Others & 31 & 24 & 0 & 5 & 0 & 1 & 0 & 0 \\
\hline \multirow{6}{*}{4} & $\begin{array}{c}\text { NATION } \\
\text { ALISM } \\
\text { AWAREN } \\
\text { ESS } \\
\end{array}$ & & & & & & & & \\
\hline & $\begin{array}{c}\text { a. } \\
\text { Religiousi } \\
\text { ty }\end{array}$ & $\begin{array}{c}3 . \\
79 \\
1 \\
\end{array}$ & $\begin{array}{c}68 \\
6\end{array}$ & $\begin{array}{c}64 \\
4\end{array}$ & $\begin{array}{l}7 \\
9\end{array}$ & $\begin{array}{l}4 \\
4\end{array}$ & $\begin{array}{l}1 \\
5\end{array}$ & 2 & 0 \\
\hline & $\begin{array}{c}\text { b. } \\
\text { Pancasila } \\
\text { Values }\end{array}$ & $\begin{array}{c}3 . \\
00 \\
9 \\
\end{array}$ & $\begin{array}{c}31 \\
2\end{array}$ & $\begin{array}{c}44 \\
8\end{array}$ & $\begin{array}{l}3 \\
0\end{array}$ & $\begin{array}{l}1 \\
8\end{array}$ & $\begin{array}{l}1 \\
5\end{array}$ & 2 & 0 \\
\hline & $\begin{array}{l}\text { c. Nation } \\
\text { Concept }\end{array}$ & $\begin{array}{c}3 . \\
34 \\
1 \\
\end{array}$ & $\begin{array}{c}14 \\
6\end{array}$ & $\begin{array}{c}58 \\
8\end{array}$ & $\begin{array}{l}3 \\
0\end{array}$ & $\begin{array}{l}1 \\
8\end{array}$ & 0 & 1 & 0 \\
\hline & $\begin{array}{c}\mathrm{d} . \\
\text { National } \\
\text { songs } \\
\end{array}$ & $\begin{array}{c}2 . \\
78 \\
5 \\
\end{array}$ & $\begin{array}{c}13 \\
1\end{array}$ & $\begin{array}{c}36 \\
8\end{array}$ & $\begin{array}{l}1 \\
9\end{array}$ & $\begin{array}{l}1 \\
8\end{array}$ & 0 & 0 & 0 \\
\hline & e. Others & $\begin{array}{c}10 \\
2 \\
\end{array}$ & 12 & 25 & 1 & 0 & 0 & 0 & 0 \\
\hline \multirow{3}{*}{5} & $\begin{array}{c}\text { BOYSCO } \\
\text { UT \& } \\
\text { DISCIPL } \\
\text { INE } \\
\text { MATERI } \\
\text { AL } \\
\end{array}$ & & & & & & & & \\
\hline & $\begin{array}{c}\text { a. Basic of } \\
\text { Boyscout }\end{array}$ & $\begin{array}{c}14 \\
7 \\
\end{array}$ & 15 & 0 & $\begin{array}{l}1 \\
3 \\
\end{array}$ & 0 & 0 & 0 & 0 \\
\hline & $\begin{array}{c}\text { b. Skills } \\
\text { and } \\
\text { Boyscout } \\
\text { techniques }\end{array}$ & $\begin{array}{c}14 \\
6\end{array}$ & 0 & 0 & 1 & 0 & 0 & 0 & 0 \\
\hline
\end{tabular}

\begin{tabular}{|c|c|c|c|c|c|c|c|c|c|}
\hline & $\begin{array}{l}\text { c. Line-up } \\
\text { of march }\end{array}$ & $\begin{array}{c}46 \\
5\end{array}$ & 11 & $\begin{array}{c}10 \\
4\end{array}$ & $\begin{array}{l}4 \\
7\end{array}$ & $\begin{array}{l}1 \\
4 \\
5\end{array}$ & $\begin{array}{l}1 \\
5\end{array}$ & 6 & 0 \\
\hline & d. Others & 40 & 23 & 7 & 0 & 0 & 6 & 0 & 0 \\
\hline \multirow{6}{*}{6} & $\begin{array}{l}\text { DEVELO } \\
\text { PMENT } \\
\text { USING: }\end{array}$ & & & & & & & & \\
\hline & $\begin{array}{c}\text { a. } \\
\text { Assesment }\end{array}$ & $\begin{array}{c}12 \\
0\end{array}$ & 42 & 40 & $\begin{array}{l}1 \\
6 \\
\end{array}$ & 1 & 1 & 0 & 0 \\
\hline & $\begin{array}{c}\text { b. } \\
\text { Profiling }\end{array}$ & 47 & 9 & 28 & 6 & 0 & 0 & 0 & 0 \\
\hline & $\begin{array}{c}\text { c. Conflict } \\
\text { Managem } \\
\text { ent } \\
\text { Training } \\
\text { (CMT) }\end{array}$ & 0 & 6 & 0 & 5 & 0 & 0 & 0 & 0 \\
\hline & $\begin{array}{l}\text { d. Life } \\
\text { Skill } \\
\text { Training } \\
\text { (LST) }\end{array}$ & 83 & 29 & 0 & 0 & 0 & 0 & 0 & 0 \\
\hline & e. Others & $\begin{array}{c}25 \\
0\end{array}$ & 0 & 0 & 0 & 0 & 0 & 0 & 0 \\
\hline \multicolumn{2}{|c|}{ SUB TOTAL } & $\begin{array}{c}38 \\
.5 \\
93 \\
\end{array}$ & $\begin{array}{l}44 \\
48\end{array}$ & $\begin{array}{l}9.0 \\
95\end{array}$ & $\begin{array}{l}6 \\
4 \\
6\end{array}$ & $\begin{array}{l}6 \\
5 \\
1 \\
\end{array}$ & $\begin{array}{l}1 \\
6 \\
0\end{array}$ & $\begin{array}{l}6 \\
1\end{array}$ & 5 \\
\hline \multicolumn{2}{|r|}{3 TOTAL } & \multicolumn{8}{|c|}{53.659} \\
\hline
\end{tabular}

Source: personality development in Indonesia, October 2017

Those data mentions that not every prisoners participate on the development program which correctional institutions held in Indonesia. Below there is datas of Personality Development Implementation in Yogyakarta Narcotics Correctional Institutions.

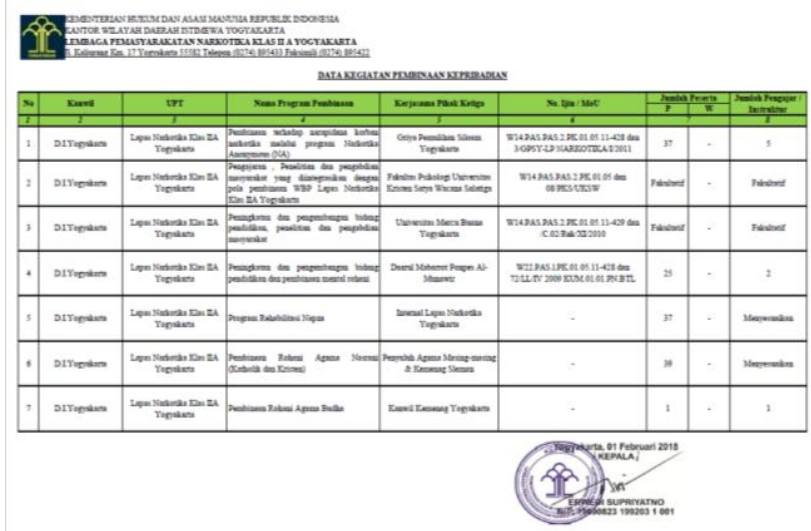

Those data shows that the execution of personality development programs are only being execcuted by third party and the role of correctional officers in only as the program facilitator.

This research have some problem formulations such: 


\section{International Journal of Engineering Applied Sciences and Technology, 2020}

Vol. 4, Issue 9, ISSN No. 2455-2143, Pages 1-6

Published Online January 2020 in IJEAST (http://www.ijeast.com)

1. How are officer's role on Personality Development of Prisoners in Yogyakarta Narcotics Correctional Institutions?

2. What are the factors to maximize officers' role on Personality Development Program of Prisoners in Yogyakarta Narcotics Correctional Institutions?

\section{METHODOLOGY}

This research using Qualitative-Descriptive method on describe the problems discussed on the study. Qualititative-Descriptive research is a research that intended to understand what were felt by the research's subjects, hollisticaly and descriptive in forms of words and language a special context which utilize natural method (Lexy Moloeng, 2007).

This research is using systematic data collection technique. Data collection is a systematic procedure dan standard to collect required data for the research. There is always correlation between data collecting method with the research's question that needed to be solved. Problems give a direction and can impact the method of data collection. There are lot problems that been formulated but in general couln not be solved because of the data collection method is not able to describe the problem or the method could not generate outcomes. If such things happen, then there is no other way for the researchers to replace the problems wanted to be solved (Moh. Nazir, 1985: 211).

This research is using triangulation source. Triangulation source is usually used to check validity of data, to compare outcomes of the interview with content of documents obtained from informations as considerations. Researchers compares observation data and the outcome of interviews. Triangulation also easily helps researchers to check the findingss with three ways:

1. Propose variation of questions;

2. Re-check with various data;

3. Utilize any possible methods to enable checking of trusted data (Lexy Moloeng, 2007: 332)

\section{RESULT AND DisCUSSION}

Result_Practice of personality development method to the correctional prisoners that been carried by the officers in Yogyakarta Narcotics Correctional Institution. There are some things must known before taking needed actions and decision, such as:

a) Correctional Prisoners Characteristic

From the study, researchers found that background of the prisoner in the institutions on below table.
Prisoners' Educational Background at Yogyakarta Narcotics Correctional Institutions

\begin{tabular}{|c|c|c|}
\hline No. & Education Background & Total \\
\hline 1 & Have no education & 25 \\
\hline 2 & Elementary School & 25 \\
\hline 3 & Junior High School & 52 \\
\hline 4 & Senior High School & 150 \\
\hline 5 & Diploma / Bachelor Degree & 30 \\
\hline \multicolumn{2}{|c|}{ Total } & 282 \\
\hline
\end{tabular}

Source: Bimkemaswat Lapsustik Yogyakarta. March 2018

The table tells that prisoners have diverse educational background which from 282 prisoners, there are 30 persons that hold diploma/bachelor degree, 150 persons hold certificate from senior high school, 52 persons graduated from junior high school, and 25 persons never took formal education. Those numbers is the reference to understands prisoners' knowledge and their understanding about what is happening around their enviroment. These background will also impact on behaviour and characteristics of correctional prisoners and impact how the guidance will be given to them.

Occupants Recapitulation Data Yogyakarta Narcotics Correctional Institutions

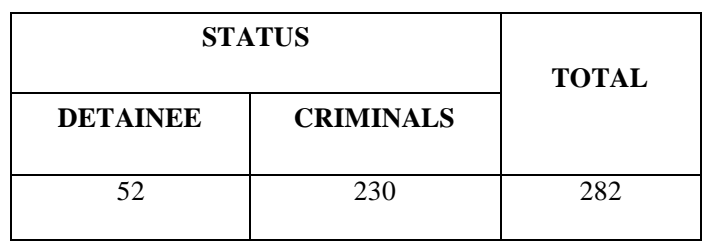

Source: Bimkemaswat Lapsustik Yogyakarta. March 2018

\begin{tabular}{|c|c|c|}
\hline NO & CASES & TOTAL \\
\hline 1 & Narcotics & 213 \\
\hline 2 & Pshycotropic & 17 \\
\hline 3 & Medical Law & 5 \\
\hline
\end{tabular}

Source: Bimkemaswat Lapsustik Yogyakarta. Maret 2018

\begin{tabular}{|c|c|c|}
\hline NO & CATEGORIES & TOTAL \\
\hline 1 & Supplier & 54 \\
\hline 2 & Dealer & 87 \\
\hline 3 & Supplier/Dealer & 8 \\
\hline
\end{tabular}




\begin{tabular}{|c|c|c|}
\hline 4 & User & 72 \\
\hline 5 & Permufakatan & 4 \\
\hline
\end{tabular}

Source: Bimkemaswat Lapsustik Yogyakarta. Maret 2018

Educational backgound is one of many factors that a person commited crime and in this case on narcotics case. With all of variety of narcotics case caused by criminals' education then guidance program needs officers and experts that have an education that adjusted to the prisoners background. The higher education the guidance officers held and adsjuted to the programs that will be operating will make it more successful.

Guidance officers must have additional skills and wide knowledge also best if they already had experience in guiding correctional prisoners. Officers must actively do the task as mandated in Act Number 12 year 1995 about Correctional that stated "Correctional Officers are Functional Officials Law Enforcer which serves Prisoners in guiding, security, and coaching. That act shows officers must have many skills that can support their performance and they have to undertand every factors that will support and inhibit Personality Development program.

b) Personality Development

Article 1 Verse 1 in Government Regulation No. 31 Year 1999 about Prisoners' Development and Guidance describe that Developing is to improve Prisoners' religiousness to God, Intellectual, attitude and behaviour, Professionality, Physical and Mental Health.

Based on Article 2 in Government Regulation No. 31 Year 1999 about Development and Guidance, cover:

1) Personality Development

Personality development directs prisoners to have mental development so in the future they will be more responsible not only to themselves, but to their family and society

2) Independence Development

Independence Development describe more about flair and skill development, so in society they can act as free and responsible person.

Based on Article 3 in Government Regulation No.

31 Year 1999 mentions that Development and Guidance about personality and independence cover things such as:

a. Religiousness

b. Nationalism

c. Intellectual

d. Physical and Mental Health

e. Law Awareness

f. Healthy Reintegration with Society

g. Work Skills

h. Production and Work Practices
The Implementation of Development in Ruling of Minister of Justice RI Number: M.02-PK.04.10 Year 1990 about Designs to Develop Prisoners. Personality Development consists of:

1. Spiritual Awareness Development

This effort intend to increase prisoners's belief especially help them understand about wrong-doing and the right thing to do.

2. Nationalism Awareness

Through P4 Programs, the efforts have goals to make prisoners aware to become good citizens that serve the nations and understand that serve the nations is half of the faith (Taqwa).

3. Intellectual Development

This efforts needed to increase prisoners' ability to think and do positive activites needen in time of corrections. Intellectual awareness can be done properly through formal or informal education.

Formal education is held as the provisions set by government so that will be huge impact for prisoners knowledge. Informal education is held as the needs and skills needed through courses, skill practices, and others support to better their softskills. Forms of non-formal that easier and cheaper to be held are activity as general lecture and the opportunity to get outside information such as reading newspaper/magazine, watch $\mathrm{TV}$, listen to the radio, and similar things. Other way to increase education level formally or informally, the prisoners able to get "Package $A$ " program or become entrepreneur.

4. Law Awareness

Law Awareness Development for the prisoners held to give law counseling that aims of awaraness of regulations as part of society, they aware of rights and obliations as citizen and also help enforcing law ad justice, protection of human dignity, order, peace, law assurance, and formed an attutide of citizens that lawobedient.

5. Society Reintegration Development.

This development can be said as developing society social life, aimed for the ex-criminals accepted by the society around them. In achieving this, they will be develop to always obedient in worshipping God, socially active. So that when they are back to the society, they already have positive trait to participate in developing their society.

Basically the development program shall work if the relation between correctional officers and prisoners tied well because they will efficiently and effectively play their role. Discussion_ Personality development that held at correctional institutions to fix prisoners' attitude is very much needed in preparing them go back to their society. Personality Development identification aimed to restore their attitude and planting noble value using third party to ensure the effectivity of personality of development. Identification process about 


\section{International Journal of Engineering Applied Sciences and Technology, 2020 \\ Vol. 4, Issue 9, ISSN No. 2455-2143, Pages 1-6 \\ Published Online January 2020 in IJEAST (http://www.ijeast.com)}

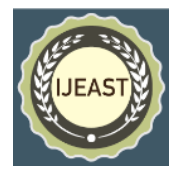

prisoners' needs in correctional institutions is needed to fill the lack of knowledge and improve their attitude.

Development purpose and target of the program is to restore the attitude of prisoners. They must know development process that given so that the program finish well and achieves its goals. Implementation of development program starts with preparing aterial about the importance of good behaviour in preparing them back to the society and polish their skills. The material of program of personality development in correctional institutions have vary activities to fufill prisoners' needs.

Yogyakarta Narcotics Correctional Institutions in implementing personality development program as an effort to restore the attitude of its prisoners run dissatifactory. The problems that occur are:

1. Lack of human resource (officer) as a specialist/instructor from correctional institutions. The implementation of personality development, third-party acted very well in developing prisoners' personality development.

2. Lack of awareness of prisoners' to participate the program. Prisoners only used this program as a precondition so they can manage reintegration program. They that felt their jail-time is not yet belong in the calculation of reintegration process only stayed in their rooms without participating in the development program.

The Personality Development program at Yogyakarta Narcotics Correctional Institutions can run efficiently if these factors was being overseen:

1. Increase numbers of professional specialist or instructor (officers), in this case the quality and quantity of officers as an effort to restore prisoners' attitude very much needed especially on personality development program. Oficers can efficiently give knowledge and trainings to the prisoners. Correctional officers must be included in education course and personality development training so they can become professional and able to implement personality development activity effective and efficiently.

2. Improve correctional prisoners' level of awareness by socialising the benefits of the program. This effort to ensure they participate on the program because of their awareness and own responsibility. Prioritizing their desire and spirit on participating in personality development program by explaining the benefits of the program for them should they participate.

\section{CONCLUSION}

1. The implementation of development program through personality development as an effort to restore correctional prisoners' attitude at Yogyakarta Narcotics
Correctional Institutions did not run well because of inhibiting factors.

2. Those Inhibiting factos that happened on implementation of personality development programs at Yogyakarta Narcotics Correctional Institutions are:

a. Lack of human resource (officers) as specialist/instructor.

b. Lack of Correctional Prisoners' awareness about the benefits of personality development activities.

3. The needs of enhancement of education and training of correctional officers, especially personality development officer related to personality development. So that officer have broad knowledge and become professional or specialisr to develop the prisoners.

4. Correctional Social workers must be able to build and improve the prisoners' awareness and attitude by increasing numbers of socialisation about the importance of personality development program also do assesment to newly correctional prisoners. So that they could understand the benefits of development program in restoring attitude as the capital when they are back at their society.

\section{REFERENCE}

[1] Abidin , Said Zainal. Public Policy. Jakarta : Suara Bebas. 2006.

[2] Arief, Barda Nawawi. Criminal Sanctions Policy in Crime Prevention. Semarang : Universitas Diponegoro. 1989.

[3] Burhan, Bungin. Quantitative Research Method. Jakarta : Kencana. 2007.

[4] Kasim, Azhar. Effectivity Measurement in Organizations. Jakarta : LPFEUI. 1993.

[5] Munir, dkk. Region's Financial Management and Policy. Yogyakarta : YPAPI. 2004.

[6] Moloeng Lexy,J. Qualitative Research Methodology . Bandung : PT.Remaja RosdaKarya. 2007.

[7] Napitupulu, Paimin. Public Service and Customer Satisfaction. Bandung : Alumni. 2007.

[8] Nazir, Ali. Research Methods and Statistics. Jakarta : LP3ES. 1999.

[9] Priyatno, Dwidja. Penitentiary Criminal Justice System in Indonesia. Bandung : Refika Aditama. 2006.

[10] Rukmana, Nana. Strategic Planning for Educational Management Model: Education Management Based on Partnership. Bandung : Alfabeta. . 2006

[11] Samosir, Djisman. Penitentiary Sanction Function in Indonesia's Criminal Justice System. Bandung : Bina Cipta. 1992. 
[12] Singarimbun, Masri dan Effendi. Survey Research Method. Jakarta : LP3ES. 1995.

[13] Steers, Richard. The Effectivity of Organizations (Behaviour Principle). Jakarta : Erlangga. 1980.

[14] Muladi. Types of Criminal Principal in New KUHP. "National Law Magazine BPHN No. Year 1989.

[15] Rancangan Kitab Undang-undang Hukum Pidana Nasional. 2005.
[16] Suryobroto, Baharuddin. Implementation of Correctional System. "Lembaga Pembinaan Hukum Nasional Magazine" No. 16 Tahun V, April , Mei, Juni 1992.

[17] Acts No. 12 year 1995 about Correctional. National Law Magazine BPHN No. Year 1989. 